This is a post-peer-review, pre-copyedit version of an article published in September 2018 in Crime, Law and Social Change. The final authenticated version is available online at: https://doi.org/10.1007/s10611-018-9791-x.

\title{
Illicit financial flows within the extractive industries sector A glance at how legal requirements can be manipulated and diverted ${ }^{1}$
}

\author{
Sophie Lemaître, PhD, Research Associate
}

\section{INTRODUCTION}

About 80 countries have abundant prized natural resources such as oil, minerals, forests or precious stones. These countries often base their economic development on the export of these resources which represent significant revenues for these economies. In some countries, it may even account for more than $90 \%$ of total exports of oil, gas and minerals, and $60 \%$ of total government revenue (IMF 2012; World Bank 2015). The extraction of natural resources may thus lead to exceptional profits. Well managed, these revenues could be a great opportunity for the economic and social development of producing countries. However, natural resources are often located in countries with a low human development index, a highlevel of corruption, and weak legal frameworks and law enforcement (UNDP 2015). In addition, revenues generated from the extraction rarely benefit to the population, including indigenous people and local communities (Oxfam International 2009). Finally, the exploitation of natural resources is often associated with illicit financial flows (Williams and Le Billon 2017).

Illicit financial flows can be defined as "money illicitly earned, transferred or utilized", ranging from corruption, money laundering to tax evasion and tax avoidance (Le Billon 2011; UNECA 2014). Illicit financial flows represent billions of dollars lost in revenues for countries all over the world. For Africa, it would be equivalent to the average annual development aid and dedicated assistance each year (UNECA 2015). Moreover, they dramatically reduce the amount of resources available for essential public services such as education or health which may undermine the achievement of the Sustainable Development Goals. The extractive industries sector (oil, gas, and minerals) is no exception. According to a study conducted in 2014 by the Organisation for Economic Co-operation and Development (OECD), this sector is the one most prone to foreign bribery (OECD 2014). In addition, Transparency International's corruption perception index seems to show a link between corruption and the extractive sector: numerous oil, gas and mining producing countries are at the bottom of the ranking each year. This is for example the case of Angola which ranked $167^{\text {th }}$ out of 180 countries in 2017 , the Republic of the Congo $\left(161^{\text {st }}\right)$, Uganda $\left(151^{\text {st }}\right)$ or Nigeria $\left(148^{\text {th }}\right)$. Corruption in this sector can take, among others, the form of petty bribe, grand corruption, extortion, undue-influence, or embezzlement in order to obtain favours,

\footnotetext{
${ }^{1}$ The Paper is dated November 2017. It is part of a wider research project conducted by the author at the Law Faculty of Rennes University - France on how stakeholders use legal frameworks and tools to perpetuate illicit financial flows within the extractive industries sector. The author would like to thank Nathalie Hervé-Fournereau for providing constructive comments on earlier drafts, resources persons met throughout this research project, the anonymous reviewers who have provided support, and Margareth Dufay for editing.
} 
This is a post-peer-review, pre-copyedit version of an article published in September 2018 in Crime, Law and Social Change. The final authenticated version is available online at: https://doi.org/10.1007/s10611-018-9791-x.

taking profit from unclear rules, manipulating the law, or turning a blind eye on illegal activities. Corruption takes place at all stages of the value chain: from allocation of licences, negotiation of contracts or procurement of goods and services to revenue collection and monitoring of operations (OECD 2015; Beevers 2015; Le Billon 2011). Tax evasion and tax avoidance in the oil, gas and mining sector are also prominent and can take various forms such as manipulation of transfer pricing, inflated costs of goods and services, under-reporting of production volumes, underestimation of the value, or treaty and law shopping (Publish What You Pay Canada 2017). For example, over the period 2000-2009, 56\% of trade mispricing from Africa came from the extractive industries sector (UNECA 2014). Numerous mechanisms and systems including the use of tax havens, secrecy jurisdictions and legal/regulatory havens, the international financial systems, or corporate vehicles enable the hiding of proceeds from corruption and tax avoidance.

Illicit financial flows within the extractive sector can be explained by numerous factors: the involvement of multiple actors (public officials, national and multinational corporations, intermediaries, etc.), the exceptional profits generated, opacity and secrecy, weak governance, etc. (Kolstad and Søreide 2009). In addition, these resources are located only in a few countries while most economies heavily rely on oil, gas and mining products to function. For example, the European Union (EU) imports over $90 \%$ of its oil, $60 \%$ of its gas, and $40 \%$ of its uranium (European Commission 2014) while China is the second world importer of oil (International Energy Agency 2016). Therefore, these resources are instrumental for countries and a major strategic issue. Obtaining secure and easy access to oil, gas and minerals is consequently crucial which can lead to illicit practices.

In order to challenge and fight illicit financial flows within the extractive industries sector, the international community has undertaken various actions and initiatives over the last two decades. International instruments to combat corruption were adopted (e.g. the OECD AntiBribery Convention in 1997, the United Nations Convention against Corruption in 2003, the Bribery Act in 2010 by the United Kingdom or the Law on transparency and bribery in 2016 by France). More and more extractive companies are putting in place compliance programmes to prevent corruption either through the development of their own programme or the implementation of anti-bribery standards such as ISO 37001:2016 (a standard adopted by the International Organization for Standardization in September 2016 that provides guidance for establishing, implementing, reviewing, and improving a compliance programme). Along with the fight against corruption, commitments have been made to revise international taxation regulations, notably through the OECD Base Erosion and Profit Shifting Action Plan, also known as the BEPS Action Plan. Some of the measures covered in the Action Plan include: automatic exchange of tax information, international exchange of country-by-country reports between tax administrations, and modifications of tax treaties. Even though these measures do not specifically target the extractive industries sector, they do provide a response to the challenges encountered in this sector. Instruments have also been designed to precisely combat illicit financial flows within the extractive industries sector. Thus, the Extractive 
This is a post-peer-review, pre-copyedit version of an article published in September 2018 in Crime, Law and Social Change. The final authenticated version is available online at: https://doi.org/10.1007/s10611-018-9791-x.

Industry Transparency Initiative (EITI) was launched in 2003 to "promote the open and accountable management of natural resources" and improve transparency (EITI 2017). It is composed of representatives from governments, the private sector and civil society organizations. 51 countries rich in oil, gas and minerals are currently implementing the "EITI Standard". The EITI Standard requires "implementing countries" (i.e. countries that have joined the initiative) to disclose a wide range of information such as companies' payments, government's revenues, revenue allocations, and social and economic spending (EITI Standard 2016). Voluntary in nature, EITI only applies to countries that have joined the initiative. Currently several extractive countries such as Uganda, Angola, or the United Arab Emirates are not part of the EITI which undermines transparency efforts undertaken throughout the sector. In addition to the EITI, home countries of extractive companies have adopted legislations that require extractive companies to disclose payments both annually and publicly made to governments in which they have extractive activities, on a country by country basis and on a project by project basis. This is for example the case of the European Union with the Accounting Directive (2013/34/EU) and the Transparency Directive $(2013 / 50 / \mathrm{EU}){ }^{2}$ Similar legislations have been adopted in the United States in 2010 (see Figure 1), in Norway in December 2013 and in Canada in December 2014. ${ }^{3}$ Switzerland is planning to do the same (Article 964a to Article 964e of the draft law aiming to modernise corporate law).

\section{Figure 1: Extractive industries transparency efforts in the United States: one step forward, two steps back}

In 2010, the United States (US) adopted the Dodd-Frank Wall Street Reform and Consumer Protection Act (also known as Dodd-Frank Act). Section 1504 entitled "Disclosure of payments by resource extraction issuers" requires companies to disclose payments made to governments in which they have exploration and/or exploitation activities. At the time, the US was the first home country of extractive companies to adopt such requirements, and thus seen as a transparency leader. In order to be fully implemented, Section 1504 requires the Securities and Exchange Commission (SEC) to draft final rules. A first set of rules were published in August 2012 which were then challenged in court by the American Petroleum Institute (API) in October 2012. ${ }^{4}$ The District Court of the District of Columbia cancelled the rules in 2013 and required the SEC to design new rules. After several twists and turns, the SEC eventually published ambitious final rules in June 2016 (Disclosure of Payments by Resource Extraction Issuers 2016). Extractive companies were expected to disclose their first

\footnotetext{
${ }^{2}$ Directive 2013/34/EU of the European Parliament and of the Council of 26 June 2013 on the annual financial statements, consolidated financial statements and related reports of certain types of undertakings, [2013] OJ L 182 and Directive 2013/50/EU of the European Parliament and of the Council of 22 October 2013, [2013] OJ L 294.

${ }^{3}$ Norway: Fastsatt av Finansdepartementet 20. desember 2013 med hjemmel i lov 17. juli 1998 om årsregnskap § 3-3 c syvende ledd og lov 29. juni 2007 nr. 75 om verdipapirhandel § 5-5 a fjerde led; Canada: Extractive Sector Transparency Measures Act (S.C. 2014, c. 39, s. 376).

${ }^{4}$ API et al. v. SEC, No. 12-1668 (D.D.C. Oct. 10, 2012). Et API v. SEC, 953 F. Supp. 2d 5 (D.D.C., 2013).
} 
This is a post-peer-review, pre-copyedit version of an article published in September 2018 in Crime, Law and Social Change. The final authenticated version is available online at: https://doi.org/10.1007/s10611-018-9791-x.

reports as of September 2018. Nevertheless, in February 2017, the Congress repealed the rules requiring the SEC to propose new rules that cannot be "substantially similar" to the rules drafted in $2016 .^{5}$ This decision was not only a major step backward in the fight against illicit financial flows in the extractive industries sector but also contrary to the current transparency trend that has led to the adoption of similar legislations in the EU, Norway and Canada. Besides, in November 2017, the US decided to withdraw from the EITI citing the fact that US laws prevented them from meeting specific provisions of the EITI. ${ }^{6}$ Thereby if the US was at one time a leader in promoting and defending transparency in the extractive industries sector, one may wonder whether with the recent political changes the US has henceforth opened the door to a new area for secrecy and opacity in this sector.

Despite these numerous and tremendous efforts, illicit financial flows within the extractive industries sector are still occurring as recently highlighted in 2016 and 2017 by the revelations of the Panama Papers and the Paradise Papers. Even though gaps, inconsistencies and weaknesses of international, regional and national initiatives and legal frameworks are key in providing space to hide proceeds from illicit financial flows, it cannot in itself explain the discrepancy between the measures adopted and the reality tainted by illicit financial flows. In that regard, globalization has played an important role. Not only has it led to the abolition of internal borders, a deregulation of financial markets, an increased ease of communication means along with interdependence and interconnection among actors but also to the development of a gray area between legality and illegality as well as between licit and illicit. Globalization has enabled actors - both public and private - to use and benefit from the different legal systems around the world while most regulations are still being designed and implemented at the national level rather than at the global and transnational level. Hence, this has created opportunities for developing creative and innovative legal techniques to perpetuate illicit financial flows in the extractive industries sector. For example, extractive companies and public officials aim for those jurisdictions that offer them what they consider to be the best arrangements, they maximise options available to them and creatively use and interpret the various legal frameworks in their favour while they sometimes contribute to the crafting of legislations (Palan 2002). This situation can be referred to as "business illegalism" or "illegalism of rights" which can be defined as the capacity of certain actors to use the law, circumvent it, divert it or manipulate it as well as influence its content in order to protect their interests, in this case to generate illicit financials flows (Foucault 1975; Delmas-Marty 2004; Lascoumes 2014). Illegalism of rights also means the possibility for these actors to benefit from special judicial treatment, for example the conclusion of transactions or settlements out of courts (Foucault 1975). This concept is closely related to the work undertaken by Edwin Sutherland on white-collar crime (Sutherland 1949).

\footnotetext{
${ }^{5}$ H.J.Res.41 - Providing for congressional disapproval under chapter 8 of title 5, United States Code, of a rule submitted by the Securities and Exchange Commission relating to "Disclosure of Payments by Resource Extraction Issuers".

6 The US decision can be accessed on the EITI website: https://eiti.org/sites/default/files/documents/signed_eiti_withdraw_11-17.pdf. Accessed 28 August 2018.
} 
This is a post-peer-review, pre-copyedit version of an article published in September 2018 in Crime, Law and Social Change. The final authenticated version is available online at: https://doi.org/10.1007/s10611-018-9791-x.

This article proposes to look at how some actors - both governments and extractive companies - within the extractive industries sector creatively use, abuse and manipulate legal frameworks to perpetuate illicit financial flows. It looks at various instances whereby these actors have interpreted and used legislations aiming at combatting illicit practices to continue "business as usual". It also provides examples of the abuse of existing legal tools such as corporate vehicles in order to perpetuate illicit financial flows. The article concludes by questioning whether Law has not in reality a dual nature: on the one side combatting corruption and tax evasion/avoidance taking place in the extractive sector and on the other side providing opportunities leading to illicit practices.

\section{DIVERTING LEGAL REQUIREMENTS PROMOTING TRANSPARENCY IN THE EXTRACTIVE SECTOR}

In order to reduce opacity, combat illicit financial flows and promote the sound management of the extractive industries sector, innovative legislations have been introduced in the last decade. However, in various instances they have been diverted or interpreted in a way that allows extractive companies or governments to perpetuate illicit financial flows. This section will look at three examples: project by project reporting under the EU Accounting Directive (1), the implementation of transparent bidding processes (2), and the disclosure of beneficial ownership (3).

\section{1) EU Accounting Directive and project by project reporting: between transparency and opacity?}

In 2013, the European Union revised the so-called Accounting and Transparency Directives. Although mainly aimed at improving accounting and transparency standards, in particular annual and consolidated financial statements of companies, these Directives have introduced new requirements for the extractive and logging industries. These provisions were designed to complement the EITI. Their final objectives are to increase transparency, provide "relevant information to civil society in order for them to hold government and business to account", and deter corruption (European Commission 2011).

The Accounting Directive dedicates an entire Chapter on this issue (insofar as the Transparency Directive is very similar to the Accounting Directive, only the latter is analysed). Chapter 10 - "Report on payments to governments" of the Directive lays down obligations for large listed and non-listed extractive and logging companies. A large company is defined as the undertaking exceeding at least two of the three following criteria: (a) balance sheet total: EUR 20000 000; (b) net turnover: EUR 40000 000; (c) average number of employees during the financial year: 250 . These companies are required to disclose payments above EUR 100000 made to governments in the countries in which they have exploration and/or exploitation activities. This must be done on a project by project basis, by governmental authority, on an annual basis, and in a separate public report. Companies were 
This is a post-peer-review, pre-copyedit version of an article published in September 2018 in Crime, Law and Social Change. The final authenticated version is available online at: https://doi.org/10.1007/s10611-018-9791-x.

expected to disclose payments in 2017 for their 2016 financial year. The United Kingdom and France were not only the first Member States to transpose the Accounting Directive (it was done in 2014) but also to implement it. ${ }^{7}$ Indeed, extractive companies from these two countries were requested to disclose their payments in 2016 for the 2015 financial year. Based on the first year of reporting, it is possible to draw lessons and highlight provisions that can be interpreted in such a way that may undermine transparency efforts and lead to opacity and secrecy. In that regard, three main aspects of the Accounting Directive and its implementation are analysed and presented in this paper (for an analysis of other aspects of the Directive, see Lemaître, Parrinello, Alliot et al. 2017; PWYP-UK 2017; Chatzivgeri et al. 2017).

\section{$\checkmark$ Disclosure of payments: room for interpretation}

Article 41.(5) of the Accounting Directive lists the payments covered by this new mandatory requirement: "(a) production entitlements; (b) taxes levied on the income, production or profits of companies, excluding taxes levied on consumption such as value added taxes, personal income taxes or sales taxes; (c) royalties; $(d)$ dividends; (e) signature, discovery and production bonuses; ( $f$ ) licence fees, rental fees, entry fees and other considerations for licences and/or concessions; and ( $g$ ) payments for infrastructure improvements". While the Directive seems to establish clear rules regarding which payments should be disclosed, it does not define the various categories of payments, leaving it up to extractive companies to make their own definition. Thus, for the same type of payment, company A could take an extensive definition of that payment while a restrictive definition would be selected by company B. For example, if BP, Shell and BHP Billiton had a similar understanding of "payments for infrastructure improvements", Tullow Oil defined it broadly to include social payments (BP 2016; Shell 2016; BHP Billiton 2017; Tullow Oil 2016). In that case, not only comparisons are challenging at country or project level but understanding what is included in the payment category is impossible. Therefore, there is a risk of introducing opacity.

Moreover, although the Accounting Directive defines the term "taxes" as including "taxes levied on the income, production or profits of companies", the use of the word "or" could lead extractive companies to choose to only report on one of these taxes while excluding the others without disclosing it, especially since the Directive does not require companies to indicate which taxes are included in their report. In fact, reports published so far have demonstrated that extractive companies do not detail which taxes are included under that category. Therefore, stakeholders willing to analyse the data disclosed would not know what the extractive companies have included under the taxes category. Thus, the definition provided by the Accounting Directive could enable extractive companies for example to conceal the fact they do not pay profit taxes or have developed tax avoidance practices. Besides, because the

\footnotetext{
${ }^{7}$ United Kingdom: The Reports on Payments to Governments Regulations (2014 n ${ }^{\circ}$ 3209). 2014. The Payments to Governments and Miscellaneous Provisions Regulations (2014 $n^{\circ} 3293$ ). 2014. France : Loi $n^{\circ} 2014-1662$ du 30 décembre 2014 portant diverses dispositions d'adaptation de la législation au droit de l'Union européenne en matière économique et financière. JORF n 0302 du 31 décembre 2014.
} 
This is a post-peer-review, pre-copyedit version of an article published in September 2018 in Crime, Law and Social Change. The final authenticated version is available online at: https://doi.org/10.1007/s10611-018-9791-x.

different types of taxes (income, production and profits) are aggregated instead of distinguished, having an insight into whether the "proper amount" of taxes has been paid is not possible. It is important to note that BHP Billiton is the only exception: the company discloses the various taxes paid separately (BHP Billiton 2017). A broader set of information per country would also be needed to identify whether an extractive company avoids taxes as underlined by the European Commission in its impact assessment (European Commission 2011).

Furthermore, Article 43.4 of the Accounting Directive requires that "the disclosure of the payments (...) shall reflect the substance, rather than the form, of the payment or activity concerned". In other words, if a payment is said to be a social contribution but looks like a tax, it should be included in the tax category. This provision was adopted to avoid payments to be artificially split or aggregated and to prevent companies from avoiding disclosure. Nevertheless, this provision allows companies to arbitrate and reclassify payments by including them into unexpected categories of payments. For example, in some countries, Total considers that royalty payments paid to governments are in fact a tax (Lemaitre, Parrinello, Alliot et al. 2017). According to the company, in all but 3 countries (South Africa, Canada and the United States), royalties are included in the tax category. It is interesting to note that Shell which operates in countries where Total is active (e.g. in Gabon and Nigeria) does disclose royalties in the royalties category (Shell 2016). Therefore, one could have expected Total to do the same. The main issue with branding a payment to a different category of payments is that it is not possible to cross-check the data disclosed. It also introduces opacity and may lead to the concealment of payments.

\section{The definition of project: an opportunity for artificially aggregating payments?}

One of the major innovations of the Accounting Directive is the mandatory disclosure of payments by extractive companies on a project by project basis which allows stakeholders to obtain detailed information about projects implemented in their countries and around the world. It also enables them to assess the contribution of extractive projects and determine whether the government receives its share. Article 41.(4) of the Directive defines "project" as "the operational activities that are governed by a single contract, license, lease, concession or similar legal agreements and form the basis for payment liabilities with a government. None the less, if multiple such agreements are substantially interconnected, this shall be considered a project". In their 2016 reports, most of the UK and French extractive companies disclosed their payments on a project by project basis (Chatzivgeri et al. 2017). However, in some instances, companies deemed that multiple contracts were to be considered as one single project which led to the aggregation of projects, and thus of payments. For example, BP and Shell aggregated all the projects they operate in the Gulf of Mexico under two main projects entitled "Gulf of Mexico - Central" and "Gulf of Mexico - West" (BP 2016; Shell 2016). Eramet aggregated as a single project payments relating to about ten mines scattered throughout New Caledonia (Lemaître, Parrinello, Alliot et al. 2017). When this is the case, it is very challenging to determine the detailed contribution of the company in a specific 
This is a post-peer-review, pre-copyedit version of an article published in September 2018 in Crime, Law and Social Change. The final authenticated version is available online at: https://doi.org/10.1007/s10611-018-9791-x.

country. This practice also raises the question of whether companies could artificially aggregate projects to conceal payments. For instance, doubts were raised about Glencore's disclosure in the Democratic Republic of the Congo (DRC) as the company published information about one project named "DRC Copperbelt Region Project" while the DRC's latest EITI report states that Glencore operates two projects: Mutanda Mining and Kamoto Copper (Glencore 2016; Moore Stephens LLP 2015).

The debate evolves around the definition and interpretation of "substantially interconnected" insofar as Article 41.(4) of the Accounting Directive is not more precise. Even though recital 45 sheds some light - "Substantially interconnected legal agreements should be understood as a set of operationally and geographically integrated contracts, licenses, leases or concessions or related agreements with substantially similar terms that are signed with a government, giving rise to payment liabilities" - it does not bring any additional information about the meaning of the terms "operationally", "geographically", and "substantially similar terms". This has led to different interpretation and understanding. Incidentally, it is interesting to note that in its 2016 guidelines on payments to governments the International Association of Oil and Gas Producers (IOGP) recognised that "the wording relating to 'substantially interconnected agreement' is open to different interpretation" (IOGP 2016). For some, "operationally", "geographically", and "substantially similar terms" are not cumulative conditions. In other words, if one of these criteria is met, projects can be aggregated. On the contrary, the Publish What You Pay coalition advocates for a different interpretation: the three conditions must be met to be able to aggregate projects (PWYP-UK 2017). This analysis seems in line with recital 45 and the Accounting Directive's spirit. In order to avoid divergent interpretation and understanding of "project" with the risk that payments may be concealed, the European Commission should publish guidelines that would provide additional information about the meaning of "substantially interconnected" and the criteria that must be met. Extractive companies could also add background information when they aggregate projects which would avoid misinterpretation from stakeholders.

\section{$\checkmark$ Joint-venture: who discloses payments?}

The Accounting Directive remains silent as to who has to disclose payments when projects are operated in joint-venture and how it should be done: shall extractive companies report their shares of payments regardless of whether they are the operator of the project or shall only the operator disclose payments made on behalf of the joint-venture? Without any further specification, the Directive leaves rooms for different interpretation and for introducing opacity. The analysis of the various reports published so far shows that extractive companies have a different understanding of this issue. For example, Total reports its share of payments irrespective of its operator status while BHP Billiton states that it does not report its payments when it is not the operator of the project (Total 2016; BHP Billiton 2017). This issue is crucial insofar as if only the operator discloses payments, a significant volume of payments would be missing and the data would be incomplete. Publish What You Pay UK provides the example 
This is a post-peer-review, pre-copyedit version of an article published in September 2018 in Crime, Law and Social Change. The final authenticated version is available online at: https://doi.org/10.1007/s10611-018-9791-x.

of Statoil: its 2015 payments report details USD 2 billion for production entitlements, of which USD 1,9 billion was attributable to production entitlement payments for projects where Statoil was not the operator (PWYP-UK 2017). In other words, if Statoil had only reported its payments as an operator, $95 \%$ of its production entitlement payments would not have been disclosed (PWYP-UK 2017). Non-reporting of payments in the case of joint-venture could open the door to concealment of illicit practices. Since one of the objectives of the Accounting Directive is to improve payments transparency, extractive companies should systematically disclose their share of payments regardless of their status of operator / nonoperator.

These findings demonstrate that within the Accounting Directive there is room for interpretation, and thus for companies to conceal information and potentially hide suspicious activities such as bribery or tax avoidance. The European Commission was expected to review and report on the implementation and effectiveness of the reporting by 21 July 2018 but it has yet to disclose its report. This review could be an opportunity to provide an answer to the issues identified and amend the Directive in order to strengthen transparency and combat secrecy.

\section{2) The abuse of transparent bidding processes}

In the extractive industries sector, competitive and open bidding processes have been put in place not only to reduce the risk of collusion and corruption caused by direct allocation of licenses and permits, a common practice in this sector, but also to promote competition among extractive companies (OCDE 2012; OCDE 2015). Despite the implementation of fair and transparent bidding processes, corruption remains high in invitations to tender. In some instances, open bidding processes are being diverted to favour companies linked to public officials and hide proceeds of corruption while in others evaluation criteria are designed in such a way to benefit a company with undisclosed beneficial ownership linked to politically exposed persons. It also happened that companies won the call for tenders while they did not demonstrate abilities to perform and achieve the requested tasks.

For a concrete example, let's take a look at the revised Code on hydrocarbons of the Republic of the Congo which was adopted on 12 October $2016 .{ }^{8}$ Article 9 provides that to be granted a permit, extractive companies shall be selected through a bidding process. The introduction of an open and competitive process in the Republic of the Congo is an important step to combat secrecy and opacity. Nevertheless, the Code on hydrocarbons does not provide additional information. Details about the bidding process are left to the adoption of a future decree by the Cabinet meeting, i.e. without the approval of the Congolese Parliament, which could open the door to a falsely transparent selection process. Moreover, Article 9 states that "under

\footnotetext{
${ }^{8}$ Loi n²8-2016 du 12 octobre 2016 portant code des hydrocarbures. Journal officiel de la République du Congo $\begin{array}{llllll}\mathrm{n}^{\circ} 8 & \mathrm{du} & 13 & \text { octobre } & 2016 . & \text { Retrieved }\end{array}$ http://www.sgg.cg/imageProvider.asp?private_resource=2588\&fn=jo_es2016_08.pdf. Accessed 28 August 2018.
} 
This is a post-peer-review, pre-copyedit version of an article published in September 2018 in Crime, Law and Social Change. The final authenticated version is available online at: https://doi.org/10.1007/s10611-018-9791-x.

exceptional circumstances" the selection of companies can be done through a "gré à gré" process, i.e. direct negotiation, but it does not define the framework under which a direct negotiation could take place. This provision leaves important room for manoeuvre that could lead to implementing the direct negotiation process as the rule and not the exception. Thus, by introducing a bidding process, the Republic of the Congo may give the impression that a transparent bidding process is in place while it risks to be otherwise.

The abuse and manipulation of transparent bidding processes are practices that can also be found within calls for tenders launched by extractive companies. Kinross Gold Corporation is a Canadian mining company under investigation by the US Department of Justice and the Securities and Exchange Commission for allegations of bribery in Mauritania (Kinross Gold Corporation 2015). The Canadian authorities have also been urged by civil society organisations to investigate (Mining Watch and Sherpa 2015). According to Le Monde, a French newspaper, whistleblowers have revealed questioning practices within the mining company. It is suspected to have selected service providers connected to the President, funded the local police' offices and furniture, and hired influential persons and politically exposed persons among the company's staff (Tilouine and Monnier 2015). Le Monde also states that Kinross Gold Corporation launched a bidding process in 2013 to provide services related to logistics within the mine in Mauritania. According to the newspaper, Maurilog, a local company with undisclosed beneficial ownership, was awarded the procurement contract while its offer was at a higher price than its competitor and it had not demonstrated expertise in the area (Tilouine and Monnier2015). In addition, one of Maurilog's shareholders would be connected to the President of Mauritania (Tilouine and Monnier 2015). The on-going investigation should provide additional information about Kinross Gold Corporation practices. Nevertheless, it highlights how a transparent bidding process could be used to conceal bribery and favour companies with political ties.

\section{3) Beneficial ownership disclosure in the extractive sector: a transparency path fraught with pitfalls}

Knowing who really owns a company has been a key advocacy theme for civil society organisations combatting secrecy and opacity within the extractive industries sector (see for example Publish What You Pay, Global Witness or Natural Resources Governance Institute's campaign on beneficial ownership). Disclosing beneficial ownership is considered to be a great deterrent to illicit financial flows. Complex corporate structure has enabled both public and private actors to hide who directly or indirectly ultimately owns the company which may contribute to conceal suspicious activities. On the contrary, transparency of beneficial ownership would make it possible to determine whether the company is closely linked to politically exposed persons. 
This is a post-peer-review, pre-copyedit version of an article published in September 2018 in Crime, Law and Social Change. The final authenticated version is available online at: https://doi.org/10.1007/s10611-018-9791-x.

In the last couple of years, the issue of beneficial ownership disclosure has been at the forefront of the EITI's work to improve transparency of the extractive industries sector. In 2013, the EITI Standard was revised, among other things, to include a provision on beneficial ownership (Requirement 3.11 of the 2013 EITI Standard). The EITI also launched a pilot project that was conducted between 2013 and 2015 in order to assess the feasibility of requiring beneficial ownership disclosure. Eleven countries took part in the pilot project (Burkina Faso, the Democratic Republic of the Congo, Honduras, Kyrgyz Republic, Liberia, Niger, Nigeria, Tajikistan, Tanzania, Togo and Zambia). Lessons learned from the pilot project led to a series of recommendations to revise the EITI Standard (EITI 2015) which took place in February 2016 with the adoption of Requirement 2.5. From 1 January 2020, implementing countries will be required to disclose beneficial ownership information in their EITI report. Countries had to publish a roadmap by 1 January 2017 detailing the various steps and milestones that the countries will undertake to comply with the EITI Standard. ${ }^{9}$ The 2016 EITI Standard also recommends that implementing countries establish a public registry of the beneficial owners of extractive companies, "including the identity(ies) of their beneficial owner(s), the level of ownership and details about how ownership or control is exerted".

According to the EITI Standard, a beneficial owner means "the natural person( $(s)$ who directly or indirectly ultimately owns or controls the corporate entity". Hence, a beneficial owner is never a corporation but always an individual. However, the EITI Standard does not provide additional information about the meaning of the terms "ultimately owns" and "controls", leaving it up to the implementing countries. This has proved to be challenging for countries that participated in the pilot project (EITI 2015). Definitions adopted by pilot countries focus primarily on control through ownership of shares or voting rights (EITI 2015) but in certain instances control can be exerted without any official relationship. For example, a politically exposed person could use their influence over the way the company is managed. In this case, no disclosure would be required. Thus, the definition of ownership and control is crucial to ensure that the vast majority of the situations are covered.

Moreover, most implementing countries have not adopted legislations on beneficial ownership. This lack of legal instrument has proved to be challenging to enforce beneficial ownership requirements. For example, in the DRC, although Congolese law does not define beneficial ownership, a non-binding definition was designed by the national multi-stakeholder group in charge of the EITI (ITIE-RDC 2015). However, as it is not mandatory for companies to disclose beneficial ownership information, several extractive companies did not provide the information or partially responded to the questionnaire submitted by the multi-stakeholder group in charge of EITI (Plateforme des organisations de la société civile intervenant dans le secteur minier 2016). Some companies also made the choice of only disclosing the legal

9 The roadmaps can be found on the EITI website. https://eiti.org/publications?search_api_views_fulltext=\&field_doc type_public=5542\&field_doc_publisher=\&f ield_doc_published_date $\% 5 \mathrm{Bmonth} \% 5 \mathrm{D}=\&$ field_doc_published_date $\% 5 \mathrm{Byear} \% 5 \mathrm{D}=\&$ field_doc_published_dat e $1 \% 5 \mathrm{Bmonth} \% 5 \mathrm{D}=\&$ field_doc_published date $1 \% 5 \mathrm{Byear} \% 5 \mathrm{D}=$. Accessed 28 August 2018. 
This is a post-peer-review, pre-copyedit version of an article published in September 2018 in Crime, Law and Social Change. The final authenticated version is available online at: https://doi.org/10.1007/s10611-018-9791-x.

owner instead of the natural person. According to them, since Congolese law does not request the disclosure of natural persons, they are not obliged to comply with the request from the multi-stakeholder group in charge of EITI (ITIE-RDC 2015).

Another issue regarding beneficial ownership relates to the establishment of an ownership threshold, i.e. a threshold from which extractive companies would be required to disclose their beneficial owners (EITI Requirement $2.5 \mathrm{f}$ ) ii.). In the DRC, a threshold of $25 \%$ was proposed while in Liberia the threshold is at 5\% (EITI 2015). Setting up a threshold means that natural persons under the agreed threshold will not be required to disclose their identity. This situation could undermine transparency efforts and provide an opportunity for opacity and concealing the identity of the ultimate owner. For example, in the DRC, the pilot project highlighted that an important number of beneficial owners of extractive companies held less than $25 \%$, and thus were not required to disclose their identity (EITI 2015). Besides, there is a significant risk that beneficial owners restructure their participation percentage to be below the threshold (NRGI 2015). Therefore, in order to ensure full transparency of beneficial ownership it would be best if no threshold was applied.

Disclosure of beneficial ownership is an important instrument to improve transparency and deter corruption. More and more countries are establishing publicly available registries of beneficial ownership of companies such as the EU Member States through the transposition of the $4^{\text {th }}$ anti-money laundering Directive. Nevertheless, implementing beneficial ownership disclosure raises numerous questions such as: How to define what a beneficial owner is? Can senior managing officials, nominee directors, administrators be considered as beneficial owners? How to define control? Which level of ownership or threshold to take into account? What types of information should be disclosed? How to check the accuracy of the information provided by the companies? How to ensure data is up to date? etc. If these issues are not properly taken into consideration, they may introduce new opportunities for unscrupulous actors to appear law abiding while not changing their practices.

Over the years, multiple initiatives and instruments have been designed and adopted to combat illicit financial flows within the extractive industries sector, closing doors for illicit practices. Nevertheless, some governments and extractive companies have shown an incredible amount of imagination to continue "business as usual" and open new gates for corruption. 
This is a post-peer-review, pre-copyedit version of an article published in September 2018 in Crime, Law and Social Change. The final authenticated version is available online at: https://doi.org/10.1007/s10611-018-9791-x.

\section{LOCAL CONTENT REQUIREMENTS: A NEW BREACH TO PERPETUATE CORRUPTION?}

Over the last few years, many resource-rich countries have introduced legislations or specific provisions known as "local content policies" or "local content requirements" into their regulatory frameworks. It is estimated that $90 \%$ of extractive countries are implementing such requirements (Ramdoo 2016). This is for example the case of Angola, Ghana and Nigeria which adopted legislations entirely dedicated to local content issues while Uganda, the Republic of the Congo and Liberia included local content provisions into their recent revision of their petroleum code. The objectives of these policies are to create jobs, promote enterprise development, and accelerate the transfer of skills and technologies at the national and local level so that the country as a whole benefits the most from extractive activities (Ramdoo 2015; Ngoasong 2014; IPIECA 2011). To that end, local content policies often require foreign extractive companies to hire local staff at various levels of competences and stages of the extractive activities (Ramdoo 2015). They can also include obligations to award a percentage of procurement of goods and services to local companies or enter into joint ventures with local partners in order to operate in the country (World Bank 2013; Ramdoo 2015). Local content policies can take various forms: they can be quantitative (i.e. when targets or quotas are set to be achieved by companies) and/or qualitative, i.e. when they require technology transfer, training of staff, etc. (Ramdoo 2016).

Although local content policies were designed to shape and strengthen economic development, they have been misused and manipulated to generate corruption, elite capture and rent-seeking in various instances (OECD 2015; Martini 2014; Ovadia 2012; Ovadia 2014; Ovadia 2016). This led Jesse Ovadia to conclude that local content requirements have " $a$ dual nature" with some actors that "see local content policies as a new way to appropriate rents" (Ovadia 2012; Ovadia 2013). The literature highlights cases where public officials "encouraged", or even imposed, companies to enter into partnerships with specifically designated local companies to operate in the country. These local companies were eventually revealed to be shell companies with disguised ownership or in which politically exposed persons and their proxies hold interests (Martini 2014). Other schemes include foreign companies establishing a consortium with local companies ultimately owned by government officials to win a bidding process for licenses. Local content legislations can also be drafted in order to favour legal entities with close connection to public officials. In that regard, the Republic of the Congo's local content provisions are interesting.

The Republic of the Congo presented to Parliament a revised Code on hydrocarbons in March 2015 with the objective of modernizing its oil and gas legal framework. The Code on hydrocarbons adopted in October 2016 (see references above) includes provisions on local content requirements in order to strengthen local expertise, build capacities and transfer technologies (from Article 143 to Article 145). More specifically, according to Article 23 of the Code, the state-owned company must hold at least $15 \%$ of shares within each oil permit 
This is a post-peer-review, pre-copyedit version of an article published in September 2018 in Crime, Law and Social Change. The final authenticated version is available online at: https://doi.org/10.1007/s10611-018-9791-x.

granted. In addition, extractive companies aiming to exploit oil and gas in the Republic of the Congo will have to partner with one or more "national private companies", i.e. a company incorporated and having its headquarters in Congo and of which more than half of the shares is either held by Congolese nationals or by legal entities of which more than half of the shares is owned by Congolese nationals. A minimum share of $15 \%$ in the oil contract has to be granted to these national private companies when a contract is awarded after the entry into force of the revised Code. The share shall be up to $25 \%$ when an oil permit is renewed. In other words, an oil contract is concluded between the state-owned company, one or more national private companies and extractive companies. Together local companies hold at least $30 \%$ of shares in an extractive project.

At first glance, these requirements seem to promote local content. Nevertheless, when one looks at the provisions in detail, it is striking to see how these rules could be diverted to perpetuate illicit financial flows. Indeed, the Code remains unclear on several occasions, opening a breach that could allow the government to impose local partners in which it has interests on extractive companies. If Article 143 states that each extractive company has to select national private companies to conclude an oil contract, it does not specify how the national private companies should be selected, neither which procedure should be put into place, when it should take place nor on which ground. Depending on the answer given to these questions, it could lead the government to intervene in the selection process and have a say when the extractive company will choose its partner. When looking at the circumstances in which Total's permit was renewed in 2015 (Total 2015), ${ }^{10}$ this may well happen. The French company was suspected by civil society organisations of selecting national private companies closely connected to the government; these national private companies having unknown beneficial ownership (Leroux 2015). It is interesting to note that at the time the permits were renewed, the revised Code on hydrocarbons had yet to be adopted. Total argued that the three local partners had been chosen by the government (Leroux 2015). If this were the case, extractive companies could in the future be tempted to select local companies that have the government's support to ensure the conclusion of the oil contract. Moreover, no requirements in terms of technical and financial capacity in the oil sector are asked to be fulfilled by the national private companies that will be selected to join oil and gas projects. Thus, the current drafting introduces ambiguities and could open the door to questioning practices. Civil society organizations had shared their concerns over these provisions and submitted comments to improve the text that were not taken into account by the Congolese Parliament (Publiez ce que vous Payez - Coalition congolaise 2015). On several occasions, they also warned the government of the risk of arbitrary granting permits to a "small group of privileged companies with the support of the public administration representatives" (Publiez ce que vous Payez - Coalition congolaise 2017). As it happens, few local companies have

\footnotetext{
${ }^{10}$ Please note that on "On December 31, 2016, Total E\&P Congo returned its interests in the Tchibouela, Tchendo, Tchibeli and Litanzi fields (65\%) to the Republic of the Congo, as the licenses have expired" (Total 2017).
} 
This is a post-peer-review, pre-copyedit version of an article published in September 2018 in Crime, Law and Social Change. The final authenticated version is available online at: https://doi.org/10.1007/s10611-018-9791-x.

already been selected for partnerships while they are known for their close ties with the government (Publiez ce que vous Payez - Coalition congolaise 2017).

The Congo's example is not unique. Studies have also looked at how local content regulations in Angola and Nigeria can be misused to generate illicit practices (See Example 1; Ovadia 2012; Nwapi 2015).

\section{Example 1: Cobalt International Energy and local content requirements in Angola}

Angola adopted local content regulations to develop its oil sector (for a detailed presentation, see Ovadia 2012). To comply with these requirements when its permits were renewed, Cobalt International Energy partnered with Sonangol, the state-owned company, and two local companies: Nazaki Oil and Gas SA and Alper Oil Limitada - which held respectively 30\% and $10 \%$ of the permit. According to Global Witness, these local companies did not have any experience in the extractive sector (Global Witness 2010). In 2011, the US Department of Justice launched an investigation for violation of the Foreign Corrupt Practices Act. ${ }^{11}$ Following the announcement of this investigation, Cobalt International Energy stated that these companies were assigned as local partners by the Angolan government (Burgis 2012). It also recognised that it had not previously worked with neither of them and was unfamiliar with them (Cobalt International Energy 2011). One can wonder why the company agreed to partner with these local companies. It was later disclosed that Nazaki Oil and Gas SA is partly owned by Aquattro, a company linked to Angolan officials: the former head of Sonangol and generals closely linked to the former President (Jeune Afrique 2012; Burgis 2015). Alper Oil Limitada's owners have so far remained undisclosed. This case highlights how local content requirements could be diverted to favour personal interests. It is important to note that in February 2017 the US Department of Justice announced the closure of the investigation against Cobalt International Energy; for the moment the reasons remain unknown (Burgis 2017).

Local content policies are seen as a promising way to ensure social and economic development in resource-rich countries (Martini 2014). However, recent cases have emphasized how the drafting and implementation of local content requirements are being used by some actors to perpetuate corruption in the extractive sector. Local content policies are not the only breaches found by some extractive companies and governments to circumvent legislations and initiatives adopted to combat illicit practices in order to generate illicit financial flows. Other areas such as mandatory social contributions and subcontracting are more and more favoured by some companies and governments to preserve their interests. For example, suspicions of corruption were raised after Statoil disclosed in 2015 that it paid to

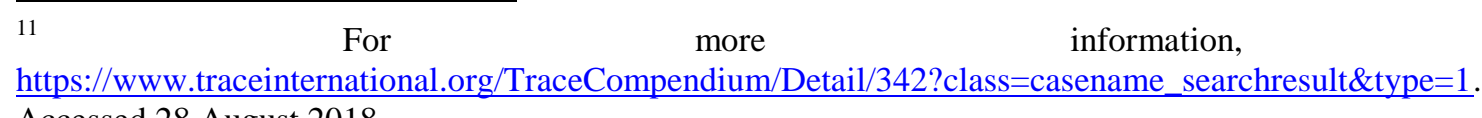
Accessed 28 August 2018. 
This is a post-peer-review, pre-copyedit version of an article published in September 2018 in Crime, Law and Social Change. The final authenticated version is available online at: https://doi.org/10.1007/s10611-018-9791-x.

Sonangol EUR 6 million for the Sonangol Research and Technology Centre, a Research Centre that apparently "exists only on paper" (Statoil 2015; Berglund 2016 a; Berglund 2016 b). These payments were part of its mandatory social contributions included in its oil contract. Other extractive companies such as BP and Cobalt International Energy have also funded this mysterious Research Centre. In March 2017, the SEC informed Cobalt International Energy that it had initiated an informal inquiry regarding the Sonangol Research and Technology Centre but in January 2018, it ended its investigation and did not bring an enforcement action against the company (Jaeger 2018).

As we have seen, despite ambitious legal framework to fight illicit financial flows within the extractive industries sector, some companies and governments have developed creative practices to perpetuate corruption and tax avoidance. Although it would be possible to amend the existing legislations to close loopholes, it would not be sufficient insofar as these actors benefit from the support of certain legal tools and the wise advice of intermediaries; an area that we will look at in the following section.

\section{THE ROLE OF CORPORATE LEGAL TOOLS AND INTERMEDIARIES}

Extractive companies and governments have access to a wide range of legal tools, in particular corporate vehicles, which they can use to perpetuate illicit financial flows in the extractive sector (1). Thanks to intermediaries such as legal and financial professional enablers, these actors are able to design schemes to continue "business as usual" (2).

\section{1) Corporate vehicles diverted and abused}

Corporate vehicles are part of today's economic activities. Thanks to these legal entities, " $a$ wide variety of commercial activities are conducted and assets are held" (OECD 2002). Their use is not illegal in itself: they could be a logical choice for some business transactions and may have a legitimate purpose, e.g. for mergers and acquisitions or estate (FATF 2006). Having recourse to these legal entities and to complex ownership and control structures do not necessarily breach national laws. In fact, it is the way these corporate vehicles are used that makes them illegitimate and illicit. They often serve to conceal illicit practices because most of them make it possible not only to preserve anonymity and confidentiality but also to create a screen between illicit financial flows and the beneficiaries. Moreover, they can easily be incorporated and dissolved (FATF 2006).

Among the various existing corporate vehicles, shell companies, offshore companies, holdings, trusts and foundations are the most favoured by actors of the extractive sector to hide proceeds from corruption or tax avoidance as recently shown by the Panama Papers and the Paradise Papers (World Bank 2011; OECD 2015; Fitzgibbon 2016). Complex layers of corporate structures are being used to disguise illicit practices and dilute corporate or individual liability. Shell companies may be established in order to conceal the award of 
This is a post-peer-review, pre-copyedit version of an article published in September 2018 in Crime, Law and Social Change. The final authenticated version is available online at: https://doi.org/10.1007/s10611-018-9791-x.

contracts to companies in which public officials or their proxies hold interests or to hide the proceeds of corruption and launder the proceeds in goods and real estate (See Example 2). Offshore companies, i.e. legal entities incorporated in country A while they only operate in country B, may be created to avoid taxes. For instance, Heritage Oil and Gas Limited was one of the first oil companies to develop extractive activities in Uganda. One of its subsidiaries based in the Bahamas held an oil permit. In July 2010, the company completed the sale of its stakes in the oil permit for USD 1,45 billion. Documents leaked as part of the Panama Papers revealed that Heritage Oil and Gas Limited's subsidiary re-domiciled from the Bahamas to Mauritius before completion of the sale to avoid paying a capital gain tax on the sale amounting to USD 404 million (ANCIR 2016; Publish What You Pay Canada 2017). Uganda and Mauritius had concluded a tax treaty allowing companies not to be taxed while Uganda and the Bahamas did not sign any such treaty. Moreover, the Paradise Papers highlighted how Glencore, a commodity trading company based in Switzerland, would have used various offshore legal entities incorporated in Bermuda, the United Arab Emirates, Switzerland and Jersey to avoid paying taxes in Burkina Faso where it holds extractive assets (Fitzgibbon 2017). Charity foundations or social development projects can also be used as channels for corruption. For example, Sociedad Química y Minera de Chile, a Chilean chemicals and mining company, agreed to pay in January 2017 to the US Department of Justice a criminal penalty of more than USD 15 million in connection with donations made to dozens of charity funds controlled by politically-connected individuals in Chile in order to be granted permits (Department of Justice 2017 a).

\section{Example 2: Shell companies and real estate from Nigeria to France}

An Oil Minister in Nigeria under Sani Abacha opened a series of bank accounts in Switzerland under his brother's name and a false identity. He also created a network of shell companies in the British Virgin Islands supported by banks in Gibraltar, Switzerland and London. In Paris, a company was registered under the form of a "société civile immobilière". It is a legal corporate entity enabling the management of assets in a flexible manner, a common corporate vehicle in France for people owning real estate. However, in various corruption cases, this type of company has been used to conceal the identity of the real owners and launder funds. In this case, it was used to purchase real estate and goods under the company's name: a mansion, a castle in Boulay Morin, a speed boat, a yacht and various art objects and antiques (Servenay 2007). The litigation case highlighted that profits generated from corruption in Nigeria with the award of oil licences led to launder funds through the various bank accounts and the purchase of real estate and goods in France (Servenay 2007).

Legal systems across the world adopted provisions enabling the creation and incorporation of corporate vehicles, in particular to favour the business sector. Initially, they were meant to ease economic activities. However, cases of illicit financial flows in the extractive industries sector highlight how shell companies, offshore companies, holdings, trusts and foundations are regularly diverted or manipulated to perpetuate corruption or tax avoidance. Therefore, 
This is a post-peer-review, pre-copyedit version of an article published in September 2018 in Crime, Law and Social Change. The final authenticated version is available online at: https://doi.org/10.1007/s10611-018-9791-x.

extractive companies and governments have multiple options at their disposal to conceal their identity and hide the proceeds of illicit financial flows. They can also count on the support of intermediaries to set up schemes and creatively generate illicit financial flows.

\section{2) The vital role of intermediaries to perpetuate illicit financial flows within the extractive sector}

Hiding proceeds of corruption or avoiding taxation from the extractive industries sector would not be possible without the support of a wide range of actors that set up corporate vehicles or bank accounts, influence or obtain favours from decision-makers and provide advice on how to generate illicit financial flows. They are often referred to as intermediaries, i.e. a "person who is put in contact with or in between two or more trading parties" (OECD 2009). Even though the use of intermediaries by extractive companies or government officials may be legitimate, they may also be used for illicit practices. $75 \%$ of foreign bribery cases (all economic sectors included) involved payments made by intermediaries (OECD 2014). The extractive industries sector is characterized by the intervention of numerous intermediaries (middle-men, banks, audit and accounting firms, law firms, etc.) who offer their support, knowledge and expertise to government officials and companies that may lead to illicit financial flows.

Middle-men have always been used in the extractive sector to influence decision-makers over a permit allocation or a favourable legislation. These individuals are chosen because they have strong ties with politically exposed persons as well as a perfect knowledge and understanding of the countries in which extractive companies operate. They are hired under the name of commercial agents or consultants and sign a service provider or a commercial contract to perform a list of tasks that would eventually be revealed to have the objective of obtaining a permit or a favourable treatment through bribery. The Giffen and the Oil-for-food Programme cases in the late $90 \mathrm{~s}$ are a classic example of the use of middle-men to obtain contracts (for more information about these cases, see the database of Trace Compedium). Although the role of these intermediaries is well known and several investigations have been conducted over the last two decades, extractive companies keep calling on these intermediaries. For example, Areva, a French uranium company currently under investigation in France, is suspected of having had recourse to an intermediary to obtain a mineral licence as well as a favourable tax treatment in Namibia (Insight 2010; Sherpa 2016). This intermediary is said to have close ties with the political party of the President of Namibia. Additional cases that came to light in 2016 and 2017 and led to investigations demonstrate that the use of middle-men is still widespread. In one of the cases, it led to convictions (See Example 3). The Unaoil scandal is also instructive in that regard. Between 2002 and 2012, Unaoil, a company registered in Monaco operating in the oil sector, is suspected of having bribed not only government officials around the world but also extractive companies on behalf of oil companies and of subcontracting companies (The Age and Huffington Post 2016). In other words, Unaoil would have acted as an intermediary for these companies so 
This is a post-peer-review, pre-copyedit version of an article published in September 2018 in Crime, Law and Social Change. The final authenticated version is available online at: https://doi.org/10.1007/s10611-018-9791-x.

that they could be allocated oil permits or subcontracts. Investigations are ongoing in the United-Kingdom, the US and Australia. More specifically, in November 2017, the Serious Fraud Office of the United-Kingdom announced charges against four individuals of conspiracy to make corrupt payments to secure the award of contracts in Iraq to Unaoil's client SBM Offshore, including the Unaoil's territory manager for Iraq and Unaoil's general territories manager for Iraq, Kazakhstan and Angola. Lastly, Public Eye's research about Gunvor's practices in the Republic of the Congo highlighted, among other things, how the commodity trading company called on middle-men to secure contracts (Public Eye 2017; Rogez 2018).

\section{Example 3: Samuel Mebiame, Africa Management Limited and bribery across Africa}

Samuel Mebiame, a dual citizen of Gabon and France, was sentenced in December 2016 to two years in prison in the US for "his role in a conspiracy to pay bribes to senior government officials across Africa" (Department of Justice 2017 b). Samuel Mebiame was a consultant for Africa Management Limited, a joint-venture between Och-Ziff Capital Management Group LLC (a US hedge fund which entered in September 2016 into a three year Deferred Prosecution Agreement with the US Department of Justice for bribery in the DRC, Chad, Niger and Libya) and an undisclosed legal entity registered in the Turks and Caicos Islands. Samuel Mebiame was in fact a "fixer" and served as an intermediary for Africa Management Limited to secure licences (Sentencing memorandum 2017). He is the son of the former Prime Minister of Gabon (1975-1990) and was politically connected to high-ranking government officials throughout Africa which may explain why Africa Management Limited selected him as a representative of the company. Between 2007 and 2015, he routinely made bribe payments to senior government officials in Niger, Chad and Guinea that were in a position to influence the award of permits (Sentencing memorandum 2017). According to court documents, Samuel Mebiame paid more than USD 4 million in bribes to government officials in Niger (Sentencing memorandum 2017). He also bribed officials in Chad which enabled Africa Management Limited to obtain a uranium concession that was held by a competing company (Sentencing memorandum 2017). It is interesting to note that when Samuel Mebiame was asked to attend anti-corruption training and sign anti-corruption representations for corporate compliances purposes, he stated that it would "kill" his business if he could not pay government officials (Sentencing memorandum 2017). Despite this statement, the jointventure kept doing business with him.

Regulating the use of intermediaries is challenging insofar as the use of intermediaries may be for legitimate reasons. Moreover, it is a fine line between corruption and undue-influence visà-vis networking or making business. Demonstrating that the activities or actions actually led to obtain a favour or a permit is not an easy task. One could require extractive companies to disclose the name of the intermediaries as well as the countries in which they had activities, e.g. as soon as the company is granted a permit. Stakeholders would then be able to scrutinize. 
This is a post-peer-review, pre-copyedit version of an article published in September 2018 in Crime, Law and Social Change. The final authenticated version is available online at: https://doi.org/10.1007/s10611-018-9791-x.

It is also important that law enforcement agencies and officers investigate both the company and the intermediary's practices.

Although middle-men have traditionally been the most favoured intermediaries in the extractive industries sector, the role of other intermediaries has come into light in the last couple of years. Lawyers and accounting firms, also known as professional enablers, have proved to play an important role (European Parliament 2017 a; European Parliament 2017 b; Murphy 2017). In particular, lawyers and law firms are key players in the schemes put in place to perpetuate illicit financial flows insofar as they could provide advice to government officials or companies on how to comply with the legal frameworks or circumvent it and on how to avoid suspicions. Thus, their legal knowledge could be used in favour of illicit practices. The European Parliament for example highlighted that "lawyers and law firms often provide investment and tax advice and assistance in the setting-up of offshore entities" (European Parliament 2017). Their involvement was emphasised by a 2015 under-cover investigation conducted by Global Witness. It revealed that out of 13 New York law firms contacted to anonymously move large sums of suspicious money without being detected, all but one provided advice and suggestions on how to do so (Global Witness 2016). The information given by the undercover investigator should have raised red flags, notably the fact that the money he held was coming from extractive companies that he helped to obtain mining concessions (Global Witness 2016). Despite this information, the various law firms indicated how to exploit the gaps within US legislations and institutions. The Panama Papers and Paradise Papers also showed the role played by law firms (See Example 4). Despite their active and regular involvement in illicit financial flows schemes, professional enablers have so far neither been under investigation nor convicted.

\section{Example 4: Paradise Papers and Appleby}

Founded in 1ate 1890, Appleby is a law firm based in Bermuda with 10 offices around the world and 470 employees. Data from the law firm leaked to the International Consortium of Investigative Journalists (ICIJ) revealed the role of Appleby, shining a light on tax engineering of multinational corporations, treaty shopping, setting up shell companies and complex ownership corporate structures, etc. In particular, ICIJ shows how lawyers at Appleby provided support to Glencore. The law firm even had a dedicated "Glencore room" at some point in time (Fitzgibbon et al. 2017). According to ICIJ, Appleby helped Glencore to reduce its taxes in Burkina Faso and Australia (Fitzgibbon 2017; Doherty 2017). The data also highlights how the company succeeded in obtaining a reduced signing bonus in the DRC with the support of Appleby. In addition, according to ICIJ, between 2009-2010, questioning deals and loans were put in place with an individual politically connected to DRC's President (Fitzgibbon et al. 2017). 
This is a post-peer-review, pre-copyedit version of an article published in September 2018 in Crime, Law and Social Change. The final authenticated version is available online at: https://doi.org/10.1007/s10611-018-9791-x.

\section{CONCLUDING REMARKS}

This paper aimed at giving a glance at how actors - both public and private - play with the rules of law to perpetuate illicit financial flows in the extractive industries sector. It is true that national, regional and international legislations and initiatives have been strengthened over the last few years and tremendously contributed to reduce illicit practices. For example, more and more extractive companies are being investigated for bribery, in particular in the US and the UK. Companies are also increasingly putting in place compliance programmes to prevent corruption. Moreover, transparency is becoming the norm for this sector thanks to the EITI and the various legislations adopted by extractive companies' home countries. In addition, taxation regulations are currently being amended.

Despite this enormous progress, some corporations and governmental officials have developed "legal tricks" and shown creativity in order to circumvent these demanding mandatory rules and initiatives and appear law abiding. Examples presented in this paper emphasized how legal provision combatting illicit financial flows within the extractive industries sector can be diverted from their original purpose, manipulated or misused. Undeniably it would be possible to close some of the breaches identified, e.g. amending the EU Accounting Directive, including local content requirements within the scope of EITI to increase scrutiny, or taking into account the challenges highlighted with beneficial ownership disclosure by giving an appropriate response (no threshold, an inclusive definition of beneficial owner, establishing public registries, etc.).

Nevertheless, these reforms and changes would not have the expected effect and impact if legal tools and intermediaries are at the service of extractive companies and government officials who are thus able to adapt quickly to legal reforms, understand how the various legal systems operate, be a step ahead and change jurisdictions accordingly, etc. As recently demonstrated by the revelations of the Panama Papers and the Paradise Papers, it is crucial that countries amend and strengthen their legal frameworks to avoid the abuse and manipulation of their legislations. For example, countries could prohibit shell companies and oblige corporations registered in their countries to demonstrate substantial economic activities within their countries. In their call for tenders, producing countries could add criteria requiring extractive companies wishing to be granted a licence to show their anti-corruption, transparency and taxation commitments. Stricter regulations and controls towards intermediaries could also be put in place. Investigations should also systematically include these stakeholders.

Legal solutions to combat these illicit practices do exist and are available. However, they heavily rely on political leadership which still seems to be lacking. The discussions within the EU regarding the revision of the $4^{\text {th }}$ money laundering directive is illustrative: the European Parliament pushed for more transparency as well as the introduction of public registry of both companies and trusts while some Member States prevented these innovative proposals to be 
This is a post-peer-review, pre-copyedit version of an article published in September 2018 in Crime, Law and Social Change. The final authenticated version is available online at: https://doi.org/10.1007/s10611-018-9791-x.

adopted despite the numerous scandals. Moreover, several countries around the world do not have an interest in changing their legal systems as they also benefit from the current situation. In view of this, civil society organizations, investigative journalists or whistleblowers have been mobilizing over the last few years to combat illicit practices in the extractive industries sector. Their actions could be a response to the challenges encountered and lead to the necessary changes.

\section{REFERENCES}

ANCIR. (2016). Leaked emails expose Heritage plot to dodge Uganda tax. ANCIR. Retrieved from https://panamapapers.investigativecenters.org/uganda/. Accessed 28 August 2018.

Beevers, M. (2015). Large-scale mining in protected areas made possible through corruption: Options for donors. U4 Brief, 2015:7, 1-4.

BHP Billiton. (2017). Economic contribution and payments to government Report 2016. Melbourne: BHP Billiton.

BP. (2016). Report on payments to governments - year ended 31 December 2015. London: BP.

Berglund, N. (2016 a, 3 February). Corruption rears its head once again. Newsinenglish. Retrieved from http://www.newsinenglish.no/2016/02/03/corruption-rears-its-head-again/. Accessed 28 August 2018.

Berglund, N. (2016 b, 8 February). More queries over Statoil in Angola. Newsinenglish. Retrieved from http://www.newsinenglish.no/2016/02/08/more-queries-over-statoil-inangola/. Accessed 28 August 2018.

Burgis, T. (2012, 21 February). US to probe Cobalt oil links in Angola. Financial Times. Retrieved from https://www.ft.com/content/284a1c78-5cb9-11e1-ac8000144feabdc0.Accessed 28 August 2018.

Burgis, T. (2015, 29 January). SEC drops corruption probe into Cobalt. Financial Times. Retrieved from https://www.ft.com/content/6378645e-a7ec-11e4-be63-00144feab7de. Accessed 28 August 2018.

Burgis, T. (2017, 9 February). US prosecutors end corruption investigation into Cobalt International Energy. Financial Times. Retrieved from https://www.ft.com/content/f0e6938108e4-3084-a16c-41d2cd600989. Accessed 28 August 2018. 
This is a post-peer-review, pre-copyedit version of an article published in September 2018 in Crime, Law and Social Change. The final authenticated version is available online at: https://doi.org/10.1007/s10611-018-9791-x.

Chatzivgeri, E., et al. (2017). Reports on Payments to Governments: A Report on Early Developments and Experiences. London: Publish What You Pay.

Cobalt International Energy. (2011). Form 10-K - Annual Report pursuant to Section 13 or 15(d) of the Securities Exchange Act of 1934 for the fiscal year ended December 31, 2010. Houston: Cobalt International Energy.

Delmas-Marty, M. (2004). Les forces imaginantes du droit: Tome 1, Le relatif et l'universel. Paris: Seuil.

Department of Justice. (2017 a). Press release - Chilean Chemicals and Mining Company Agrees to Pay More Than \$15 Million to Resolve Foreign Corrupt Practices Act Charges. Department of Justice.

Department of Justice. (2017 b). Press release - Gabonese-French Dual Citizen Sentenced to 24 Months Imprisonment for Bribing African Officials. Washington, DC: Department of Justice.

Doherty, B. (2017, 5 November). Glencore's Australian arm moved billions through Bermuda. The guardian. Retrieved from https://www.theguardian.com/news/2017/nov/05/glencoreaustralian-arm-moved-billions-through-bermuda. Accessed 28 August 2018.

EITI. (2015). Beneficial ownership pilot evaluation report. Oslo: EITI.

EITI. (2016). EITI Standard. Oslo: EITI.

EITI. (2017). Fact sheet - The global standard for the good governance of oil, gas and mineral resources. Oslo: EITI.

European Commission. (2011). Commission Staff Working Paper, Part II, Impact Assessment for financial disclosures on a country by country basis. SEC (2011) 1289 final.

European Commission. (2014). Communication from the Commission to the European Parliament and the Council European - Energy Security Strategy. COM (2014) 330 final.

European Parliament. (2017 a). Draft report on the inquiry on money laundering, tax avoidance and tax evasion (2017/2013(INI)) - Committee of Inquiry to investigate alleged contraventions and maladministration in the application of Union law in relation to money laundering, tax avoidance and tax evasion. Brussels: European Parliament.

European Parliament. (2017 b). Role of advisors and intermediaries in the schemes revealed in the Panama Papers - Study for the PANA Committee. Brussels: European Parliament. 
This is a post-peer-review, pre-copyedit version of an article published in September 2018 in Crime, Law and Social Change. The final authenticated version is available online at: https://doi.org/10.1007/s10611-018-9791-x.

FATF. (2006). The misuse of corporate vehicles, including trust and company service providers. Paris: FATF.

Fitzgibbon, W. (2016, 25 July). New Panama Papers series exposes secret deals in Africa. ICIJ. Retrieved from https://www.icij.org/blog/2016/07/new-panama-papers-series-exposessecret-deals-africa/. Accessed 28 August 2018.

Fitzgibbon, W. (2017, 8 November). Development Dreams Stand Still While Mining Money Moves Offshore. A village hoped for a better life. Burkina Faso expected more tax revenue. Residents and officials said Glencore gave them neither. ICIJ. Retrieved from https://www.icij.org/investigations/paradise-papers/development-dreams-stand-still-miningmoney-moves-offshore/. Accessed 28 August 2018.

Fitzgibbon, W., et al. (2017, 5 November). Room of secrets reveals Glencore's mysteries. ICIJ. Retrieved from https://www.icij.org/investigations/paradise-papers/room-of-secretsreveals-mysteries-of-glencore/. Accessed 28 August 2018.

Foucault, M. (1975). Surveiller et punir. Paris: Gallimard.

Glencore. (2016). Glencore - Payments to governments report 2015. Baar: Glencore.

Global Witness. (2010). Press release - Goldman Sachs backs Angolan oil deal despite corruption risks. London: Global Witness.

Global Witness. (2016). Lowering the Bar. London: Global Witness.

Halland, H., Lokanc, M., \& Nair, A. (2015). The Extractive Industries Sector: Essentials for Economists, Public Finance Professionals, and Policy Makers. Washington, DC: World Bank.

IMF. (2012). Macroeconomic Policy Frameworks for Resource-Rich Developing Countries.

Washington, DC: IMF.

Insight. (2010, 10 May). The Areva Exception. Insight. Retrieved from http://www.insight.com.na/the-areva-exception/. Accessed 28 August 2018.

International Energy Agency. (2016). Key world energy statistics. Paris: International Energy Agency.

IOGP. (2016). The Reports on Payments to Governments Regulations 2014 (as amended) Industry Guidance. London: IOGP. 
This is a post-peer-review, pre-copyedit version of an article published in September 2018 in Crime, Law and Social Change. The final authenticated version is available online at: https://doi.org/10.1007/s10611-018-9791-x.

IPIECA. (2011). Local content strategy: a guidance document for the oil and gas industry. London: IPIECA.

ITIE-RDC. (2015). Propriétaires réels des industries extractives - Rapport du projet pilote. Kinshasa. ITIE-RDC.

Jaeger, J. (2018, 31 January). Cobalt: SEC ends second FCPA probe. Compliance Week. Retrieved from https://www.complianceweek.com/blogs/enforcement-action/cobalt-sec-endssecond-fcpa-probe. Accessed 28 August 2018.

Jeune Afrique. (2012, 15 June). Angola : Manuel Vicente ne croit pas à la corruption. Jeune Afrique. Retrieved from http://www.jeuneafrique.com/27791/economie/angola-manuelvicente-ne-croit-pas-la-corruption/. Accessed 28 August 2018.

Kolstad, I., \& Søreide, T. (2009). Corruption in natural resource management: Implications for policy makers. Resources Policy, 34(4), 214-226 (2009). https://doi.org/10.1016/j.resourpol.2009.05.001.

Lascoumes, P., \& Nagels, C. (2014). Sociologie des élites délinquantes - De la criminalité en col blanc à la corruption politique. Paris: Armand Colin.

Le Billon, P. (2011). Extractive sectors and illicit financial flows: what role for revenue governance initiatives?. U4 Anti-corruption Resource Centre, 2011:13, 1-45.

Lemaître, S., Parrinello, Q., Alliot, C., et al. (2017). Beyond Transparency: Investigating the New Extractive Industry Disclosures. Paris: Oxfam.

Leroux, M. (2015, 1 September). Local partners muddy waters of Total's offshore contracts. The Times. Retrieved from https://www.thetimes.co.uk/article/local-partners-muddy-watersof-totals-offshore-contracts-jkc9rvbmj6f. Accessed 28 August 2018.

Kinross Gold Corporation. (2015). News release - Kinross Addresses Regulatory Review of West Africa Operations. Toronto: Kinross Gold Corporation.

Martini, M. (2014). Local content policies and corruption in the oil and gas industry. U4 Expert Answer, 2014:15, 1-9.

Mining Watch, \& Sherpa. (2015). News release - NGOs Urge RCMP To Investigate Kinross Over Reports of Corruption in Africa. Paris: Sherpa.

Murphy, R., \& Stausholm, S. N. (2017). The Big Four - a study of opacity. Brussels: GUE/NGL. 
This is a post-peer-review, pre-copyedit version of an article published in September 2018 in Crime, Law and Social Change. The final authenticated version is available online at: https://doi.org/10.1007/s10611-018-9791-x.

Ngoasong, M. Z. (2014). How international oil and gas companies respond to local content policies in petroleum-producing developing countries: A narrative enquiry. Energy Policy, 73, 471-479 (2014). https://doi.org/10.1016/j.enpol.2014.05.048.

NRGI. (2015). Owning Up: options for disclosing the identities of beneficial owners of extractive companies. Washington, DC: NRGI.

Nwapi, C. (2015). Corruption vulnerabilities in local content policies in the extractive sector: An examination of the Nigerian Oil and Gas Industry Content Development Act, 2010. Resources Policy, 46(2), 9296 (2015). https://doi.org/10.1016/j.resourpol.2015.09.001.

Moore Stephens LLP. (2015). Rapport ITIE RDC 2014. London: Moore Stephens LLP.

OECD. (2002). Behind the corporate veil - using corporate entities for illicit purposes. Paris: OECD.

OECD. (2009). Typologies on the role of intermediaries in international business transactions. Paris: OECD.

OECD. (2012). Stocktaking of business integrity and anti-bribery legislation, policies and practices in twenty African countries. Paris: OECD.

OECD. (2014). OECD Foreign Bribery Report. Paris: OECD.

OECD. (2015). Corruption in the extractive value chain - typology of risks, mitigation measures and incentives. Paris: OECD.

Ovadia, J. S. (2012). The Dual Nature of Local Content in Angola's Oil and Gas Industry: Development vs. Elite Accumulation. Journal of Contemporary African Studies, 30(3), 395417 (2012). https://doi.org/10.1080/02589001.2012.701846.

Ovadia, J. S. (2013). The Reinvention of Elite Accumulation in Angola: Emergent Capitalism in a Rentier Economy. Cadernos de Estudos Africanos, 25, 33-63.

Ovadia, J. S. (2014). Local content and natural resource governance: The cases of Angola and Nigeria. The Extractive Industries and Society, 1(2), 137-146 (2014). https://doi.org/10.1016/j.exis.2014.08.002.

Ovadia, J. S. (2016). Local content policies and petro-development in Sub-Saharan Africa: A comparative analysis. Resources Policy, 49, 20-30 (2016). https://doi.org/10.1016/j.resourpol.2016.04.003. 
This is a post-peer-review, pre-copyedit version of an article published in September 2018 in Crime, Law and Social Change. The final authenticated version is available online at: https://doi.org/10.1007/s10611-018-9791-x.

Oxfam International. (2009). Lifting the Resource Curse How poor people can and should benefit from the revenues of extractive industries. London: Oxfam.

Palan, R. (2002). Tax Havens and the Commercialization of State Sovereignty. International Organization, 56(1), 151-176.

Plateforme des organisations de la société civile intervenant dans le secteur minier. (2016). Memorandum sur la mise en œuvre du processus ITIE-RDC : analyse des rapports 2013 et 2014. Kinshasa: Plateforme des organisations de la société civile intervenant dans le secteur minier.

Public Eye. (2017). Gunvor au Congo - Oil, cash payments and embezzlement. The adventures of a Swiss trader in Brazzaville. Lausanne: Public Eye.

Publiez ce que vous Payez - Coalition congolaise. (2015). Note de position de Publiez ce que vous payez - Congo relative au Projet de code des hydrocarbures. Brazzaville: Publiez ce que vous payez - Coalition congolaise.

Publiez ce que vous payez - Coalition congolaise. (2017). La lettre de la Coalition. n5, 1-14.

Publish What You Pay Canada. (2017). Many ways to lose a billion - How governments fail to secure a fair share of natural resource wealth. Ottawa: Publish What You Pay Canada.

PWYP-UK. (2017). Guidance for reporting payments to governments - March 2017. London: PWYP-UK.

Ramdoo, I. (2015). Unpacking local content requirements in the extractive sector: what implications for the global trade and investment frameworks. Workshop Paper. The E15 Initiative. Retrieved from http://e15initiative.org/wp-content/uploads/2015/07/ExtractiveRamdoo-FINAL.pdf. Accessed 28 August 2018.

Ramdoo, I. (2016). Local content policies in mineral-rich countries - an overview. Discussion Paper $\mathrm{n}^{\circ}$ 193. European Centre for Development Policy Management. Retrieved from http://ecdpm.org/wp-content/uploads/ECDPM-Discussion-Paper-193-Local-Content-PoliciesMineral-Rich-Countries-2016.pdf. Accessed 28 August 2018.

Rogez, O. (2018, 28 August). Un ex-négociant en pétrole condamné pour corruption au Congo et en Côte d'Ivoire. RFI. Retrieved from http://www.rfi.fr/afrique/20180827corruption-congo-cote-ivoire-gunvor-suisse-ex-negociant-petrole-condamne-public-eye.

Accessed 28 August 2018. 
This is a post-peer-review, pre-copyedit version of an article published in September 2018 in Crime, Law and Social Change. The final authenticated version is available online at: https://doi.org/10.1007/s10611-018-9791-x.

Servenay, D. (2007, 22 November). Un ex-ministre nigérian du Pétrole condamné en France. Rue 89. Retrieved from https://www.nouvelobs.com/rue89/rue89monde/20071122.RUE2372/un-ex-ministre-nigerian-du-petrole-condamne-en-france.html.

Accessed 28 August 2018.

Shell. (2016). Report on payments to governments for the year 2015. The Hague: Shell.

Sherpa. (2016). Corruption internationale - changer les pratiques : l'affaire Areva-UraMin. Paris: Sherpa.

Statoil. (2016). 2015 Payments to governments. Oslo: Statoil.

Sutherland, E. (1949). White collar crime. New York: The Dryden Press

Tilouine, J., \& Monnier, X. (2015, 13 November). Kinross, en Mauritanie, la malédiction de la mine d'or de Tasiast. Le Monde. Retrieved from https://www.lemonde.fr/afrique/article/2015/11/13/kinross-en-mauritanie-la-malediction-dela-mine-d-or-de-tasiast_4809432_3212.html. Accessed 28 August 2018.

The Age, \& Huffington Post. (2016, 31 March). The Bribe Factory. The Huffington Post. Retrieved from https://www.theage.com.au/interactive/2016/the-bribe-factory/. Accessed 28 August 2018.

Total. (2015). Communiqué de presse - Renouvellement des licences du secteur sud. Paris: Total.

Total. (2016). 2015 edition - Registration document. Paris: Total.

Total (2017). 2016 edition - Form 20-F. Paris: Total.

Tullow Oil. (2016). Tullow Oil plc 2015 Annual Report and Accounts. London: Tullow Oil.

UNDP. (2015). Human Development Report 2015 'Work for Human Development'. New York: UNDP.

UNECA. (2014). Illicit financial flows - why Africa needs to "track it, stop it and get it". Addis Ababa: UNECA.

UNECA. (2015). Report of the High Level Panel on Illicit Financial Flows from Africa Track it! Stop it! Get it!. Addis Ababa: UNECA. 
This is a post-peer-review, pre-copyedit version of an article published in September 2018 in Crime, Law and Social Change. The final authenticated version is available online at: https://doi.org/10.1007/s10611-018-9791-x.

United States of America vs. Samuel Mebiame, Sentencing memorandum. 2017. Retrieved from https://globalinvestigationsreview.com/digital_assets/37602178-4a77-470a-a4c3978aed731248/US-v-Samuel-Mebiame-Sentencing-memorandum-24-April-2017.pdf.

Accessed 28 August 2018.

Williams, A., \& Le Billon, P. (2017). Corruption. Natural Resources and Development: From Resource Curse to Political Ecology. Cheltenham and Northampton, MA: Edward Elgar Publishing.

World Bank. (2011). The Puppet Masters. Washington DC: World Bank.

World Bank. (2013). Local content policies in the oil and gas sector. Washington DC: World Bank. 